
Prace Komisji Geografii Komunikacji PTG

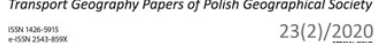

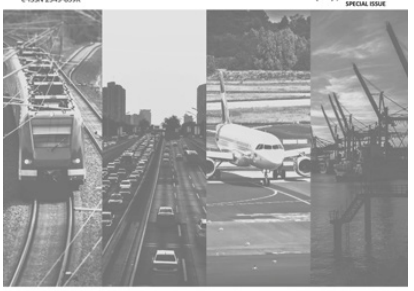

Transport Geography Papers of Polish Geographical Society

$2020,23(2), 35-39$

DOI 10.4467/2543859XPKG.20.005.12103

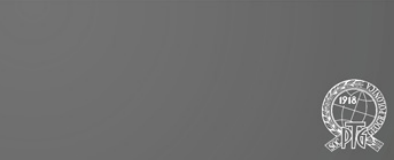

Received: 21.04.2020

Received in revised form: 05.05.2020

Accepted: 05.05.2020

Published: 15.06 .2020

\title{
COVID-19 AND TOURISM - THE CASE OF POLAND
}

\section{COVID-19 i turystyka - przypadek Polski}

\section{Tomasz Wiskulski}

Faculty of Physical Culture, Gdansk University of Physical Education and Sport, Górskiego 1, 80-336 Gdańsk, Poland

e-mail: tomasz.wiskulski@awf.gda.pl

\section{Citation:}

Wiskulski T., 2020, COVID-19 and tourism - the case of Poland, Prace Komisji Geografii Komunikacji PTG, 23(2), 35-39.

\begin{abstract}
Despite widespread information about COVID-19 disease in the media, the world did not want to acknowledge that the epidemic could get out of hand and reach Europe in a short time. This shortly led to an almost complete halt in the tourism market. Administrative decisions, whose rapid implementation was aimed to be pre-emptive action for the development of the epidemic, were not without significance for the sector of tourist services. Steps taken in Poland were perceived by many people as too drastic. This is proved, in consistence with the Senbeto and Hon model (2020), by the fact that part of the society did not obey the restrictions, taking previously planned tourist trips. The article presents actions taken at the national level and restrictions resulting from actions taken with regard to mobility related to the implementation of tourist objectives. An attempt was also made to present the consequences of the pandemic for the tourist traffic in national terms.
\end{abstract}

Keywords: COVID-19, restrictions, pandemic, tourism 


\section{Introduction}

Crises and disasters not only threaten the tourism industry, but they also have a profound impact on tourists' behavior. For example, the 2014 Ebola crisis affected the development of tourism in West Africa (Adam, 2015), and the SARS outbreak in 2003 reduced demand for tourism in East Asia (Mao, et al., 2010). Research on the above topics in the field of tourism focused on analyzing their impact on the volume of tourism traffic. Little space was devoted to studying patterns of evolutionary changes, such as the variability of reactions before, during and after the crisis, and the relationship between the type of crisis and the tourists' responses associated with them. The research conducted on the avoidance of hazards indicates that traveling during one affects the tourists' behavior (Kozak, et al., 2007). It was also noted that tourists returning to a tourist destination are more sensitive to crises compared to tourists visiting the destination for the first time (Fuchs, Reichel, 2011).

In mid-December 2019, the first cases of a new disease causing pneumonia symptoms were recorded. The new disease, in terms of the genetic sequence, proved similar to the SARS virus (Hui, et al., 2020). Thanks to the movement of people associated with the celebration of the Chinese New Year on January 13,2020 , the first recorded case of the virus outside China was confirmed. Already on January 24, the first cases of the disease were reported in Europe. On January 28 , the number of people who died from the virus exceeded 100 - all in China. Already on February 2, the first death outside China was recorded. On February 25, the number of persons infected in the world exceeded 80,000. With such significant dynamics, it was only on March 11 that the WHO CEO Tedros Adhanom Ghebreyesus gave the disease the status of a pandemic. The number of infected people worldwide amounted to 1 million on April 2, rising to 1.5 million by April 8. Such dynamics is, of course, associated with people's mobility.

\section{Literature review}

Regardless of the type of crisis and its magnitude, it causes shock and stress at and around destinations. There are numerous studies on the impact of a crisis on the volume of tourist flows and travel decisions (Kozak, et al., 2007; Law, 2006; Mason, et al., 2005). The COVID-19 pandemic, despite its greater importance for human health and safety, is a challenge for the tourism industry. Lee, et. al., 2012 and Yang, et. al., 2020 have reported the hitherto influence of diseases on tourism.
Analyzing economic crises in connection with those based on health safety, one can notice significant differences in their consequences. In the case of short- and medium-haul tourism, the participants are less sensitive to the consequences in the case of economic crises (Song, et al., 2011) than in the case of epidemics (Senbeto, Hon, 2020).

Economic consequences are additional consequences of the outbreak that have a significant impact on tourist mobility. The 2003 SARS epidemic resulted in an increase in unemployment in Hong Kong, a reduction of tourism revenues and a reduction of the number of tourists in the first place. In the long run, this resulted in the emergence of further problems. Namely, there was a slump in terms of access to human resources in the form of excessive use of unpaid leaves, dismissing employees and the collapse of many tourism companies (Chen, 2011). In turn, the economic consequences of the SARS epidemic contributed to a decline in the mobility of Hong Kong's residents, which had a significant impact on the markets of tourist services in third countries.

In the era of air transport, a deadly disease can spread quickly throughout the planet. The SARS virus traveled around the planet by airlines appearing in the Chinese province of Guangdong in November 2002. It took it a year to get to Toronto, Canada (Lee, et al., 2012).

The research on minimizing uncertainty during travel allowed stating that traveling during an epidemic mainly depends on the degree of perceiving the risk (Lee, Chen, 2011). The main indicators of tourists avoiding uncertainty during an epidemic include a decrease in the number of visitors and a shorter duration of stay. According to official statistics, over 8,000 persons contracted SARS around the world, and 774 of them died. Due to the panic accompanying the virus, around 3 million people from the tourism sector lost their jobs, and tourist flows in Asia decreased by $70 \%$ (McKercher, Chon, 2004).

Interpretation of the crisis shapes the way a tourist perceives it. The following study focuses on the evolution of pandemic-related behavior - pre-crisis: perception, during crisis: execution and post-crisis: evaluation. Figure 1 presents the stages of perception of the epidemic. When a crisis occurs, perception that affects tourists' behavior and their decisions remains crucial (Floyd, et al., 2004). The second stage occurs during the epidemic. It presents a real change in traveling during the crisis. Although research shows that tourists generally refrain from traveling, some of them travel regardless of the occurrence of the epidemic (Uriely, et al., 2007). It was noted that tourism associated with visiting friends and relatives is the most resistant to change (Backer, Ritchie, 2017). 


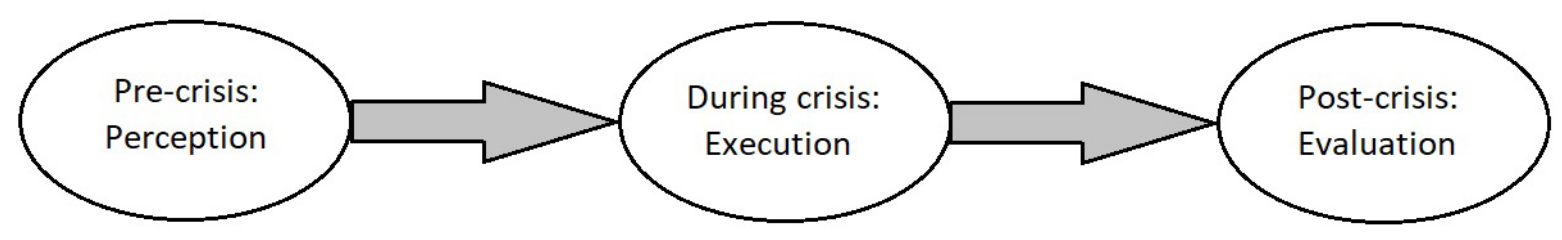

Fig. 1. Evolution of tourist behaviours across three phases of the crisis..

Source: Senbeto, Hon, 2020.

Post-crisis evaluation defines the changes that occurred in the behavior of tourists after the end of the epidemic. Because epidemics are unpredictable, they cause shock and stress both at the destination and among tourists whose perception is influenced by fear and uncertainty. Research results suggest that anxiety related to uncertainty may negatively affect the intention to visit the destination (Hon, et al., 2014).

\section{Introduced restrictions}

With the current dependence of the economy on transport, both globally and locally, and being aware of the sensitivity of the sector of tourist services to all stimuli and knowing the dynamics of spreading the virus, it is impossible to unequivocally determine the consequences of its occurrence for transport and tourism. According to current knowledge, it is known that the virus is transmitted mainly by way of droplet infections, i.e. in direct contact between people. The main problem with infections is the time of incubation of the virus itself, which was estimated at 5.1 days (Lauer, et al., 2020). This means that in this asymptomatic period, a person may be a carrier without being aware of infecting people around them. Unfortunately, this information was not published until March 10, i.e. 3 months after the first official cases of the infection.

In order to limit spreading the virus, restrictions were introduced, as a result of which the people's mobility was reduced with almost a complete halt of the tourist traffic. In the regulation issued on 13 March 2020 regarding the announcement of a state of epidemic emergency in the territory of the Republic of Poland (Dz.U. 2020, poz. 433 - Journal of Laws 2020, item 433), the Minister of Health introduced restrictions on the functioning of tourist accommodation establishments and short-term accommodation rental. However, in the regulation of 20 March 2020 on the announcement of the state of the epidemic in the Republic of Poland (Dz.U. 2020, poz. 491 - Journal of Laws 2020, item 491), which further restricted business activity, information on accommodation facilities was not included. The Ministry explained the changes by saying that not the business ban itself was important, but the ban on movement, which came into force on March 15 for a period of 10 days.

The ban of March 15 involved an obligation of a 14-day home quarantine for persons who came to Poland, a ban on foreigners entering Poland, except for spouses or children of Polish citizens, holders of the Pole's Card, persons with the right of permanent or temporary residence, and persons with a work permit. Importantly, this restriction did not apply to Polish citizens working in neighboring countries and returning to the country every day. International air and rail connections were also suspended. People from abroad were able to return only by planes chartered by travel agencies or by road transport - cars, buses and coaches. Other people who planned to return to the country by air were forced to take advantage of the "LOT home"1 campaign. Ultimately, 55,000 people used this offer.

Due to the increase in the incidence dynamics, on March 25 it was announced that the validity period of the restrictions would be extended until April 13. Restrictions on international passenger traffic were tightened since March 27, as persons working outside the country previously exempted from the obligation of a 14-day quarantine were now obliged to isolation. On April 10, due to the development of the pandemic, it was announced that the ban on crossing borders on the way to Poland would be maintained until May 3.

By mid-April 2020, restrictions on international travel had been introduced in almost every country with which Poland has direct land and sea passenger connections. Only such countries as Belarus and Sweden offered limited prevention in comparison to other countries. Belarus authorities, despite re-

This is a pun on words. LOT is the national airline of Poland, but the word also means "flight". Therefore, the name of the campaign read "FLIGHT home" but it could only be implemented by the Polish national carrier. 
ported cases in the country, did not introduce any restrictions on mobility, while denying information about the threat. In Sweden, on the other hand, since 19 March, borders were closed for 30 days for people from outside the EU, unless they had a residence or work permit.

According to the theory of tourists' perception of the crisis (Senbeto, Hon, 2020), in many countries the first mention of the virus did not cause a complete reduction of the tourist traffic. There were many cases in which travel agencies refused to cancel a tourist event and refund $100 \%$ of the costs incurred by tourists, thus wanting to force potential tourists to participate in trips - often effectively. Local authorities were also responsible for the situation. In the tourist town of Ischgl in Tyrol, despite the knowledge about infections, the activity of gastronomic and accommodation base was not limited. The problem was reported by Iceland's authorities on 1 March, and the Tyrol authorities did not react. Only in view of reports from Denmark, Germany, Norway and Sweden on March 10, all bars in the town were closed. However, ski lifts and accommodation facilities were allowed to operate. On March 13 the Paznaun Valley was put in quarantine; however, ski lifts bringing skiers could operate until March 15. Also, activities on the part of tourists did not tend to reduce movement. Such behavior was favored by spring break at universities in the USA, rising temperatures and Easter holidays.

It was only the media coverage of the situation in the main winter tourist destinations, the announcement of the state of pandemic by the WHO, and the introduction of restrictions on movement in individual countries that resulted in almost a complete stop of tourism.

\section{Methods of counteracting}

Observing the dynamics of spreading the virus, it can be assumed that the period of the pandemic will not end by the end of the 2020 summer tourist season. One should take into account bans on organizing festivals and limiting package tourism, and all attempts to organize sporting events involving supporters should be considered a manifestation of a lack of responsibility.

In the sector of tourist services, measures were taken at an early stage to reduce the consequences of the pandemic. The first ideas to eliminate the effects include actions for all sectors of the economy. Enterprises, after meeting certain conditions, may, among others, apply for exemption from paying social security contributions and extend the deadline for paying taxes (Dz.U. 2020, poz. 694 - Journal of Laws 2020, item 694). Actions undertaken specifically for tourist entities include: a possibility to extend the deadline for refunding deposits paid by tourists for participation in a tourist event which was canceled due to the pandemic by 180 days, to 194 days, and a possibility to issue the tourist a voucher, covered by a solvency guarantee, in the amount of not less than the amount paid for the tourist event to be used within one year from the date of issue (Dz.U. 2020, poz. 695 - Journal of Laws 2020, item 695. These activities are aimed to reduce the burden on tour operators thus increasing their chances of remaining on the market.

Unfortunately, at the early stage of introducing these tools, the authorities failed to focus on regulating relationships between individual entities on the market of tourism services. For example, accommodation facilities in which places had been booked as part of a specific tourist event are not obliged to return deposits, while such a refund is obligatory in cash or in the form of a voucher by an operator to the customer. Instead, accommodation facilities often offer vouchers with varying expiry dates.

Further actions are also planned to save the sector of tourist services. The media report about the planned $1000+$ program for tourism. However, the final principles of the program are not known. It is known, however, that it will not be addressed to all citizens, but only to the poorest. Also this program can only be implemented in the case of domestic tourism, so that the money spent flows back into the budget in the form of taxes. The presented program, due to its assumption, may turn out to be too much of a burden for tourist enterprises, as it is not known how travel agencies would refund money from the state budget, while being obliged to refund deposits from their own funds.

In mid-April four stages of defrosting the economy and social life were presented. The second stage gives hope for the revival of the sector of tourist services, as accommodation facilities are to be opened. Of course, the introduction of each subsequent stage will depend on the degree of development of the pandemic in Poland.

\section{Conclusions}

With the current trend of the development of the pandemic being maintained and with the gradual defrosting of the economy, the offer on the market of tourist services is likely to resume still in the current tourist season. The epidemiological situation and the accompanying restrictions on movement in the areas of tourist reception are also significant. However, the mere possibility of access to services does not mean increased interest. 
By observing the changes in tourism that took place after the SARS and Ebola epidemics, one-day tourism will recover the fastest. Tourists will travel to places close to where they live, because such services will give them an opportunity to respond more quickly to emerging threats. Therefore, it will be important to develop a strategy for promoting local tourism and ensuring accessibility at the local level. Similar dynamics will also take place in the case of individual low-budget trips. On the one hand, their attractiveness will be crucial in order to maintain distance and limit the spread of the pandemic; on the other hand, low-budget trips will be an attractive alternative, because tourists, due to lower disposable income, can pay more attention to prices.

A return to the pre-pandemic situation is far from being achieved. An example is the situation in China, where on March 25, entering the Hubei Province was allowed and public transport was partially resumed, and Wuhan was unblocked on March 8 . The mobility allowed identifying more cases of infection in a short time. Also the situation in Suifenhe, a city near the Chinese-Russian border, shows a long way to overcome the pandemic. In the city there were 123 cases of the virus in people coming from Russia (mainly from business trips) and 137 asymptomatic infections in the local population.

\section{Bibliography}

Adam I., 2015, Backpackers' risk perceptions and risk reduction strategies in Ghana, Tourism Management, 49, 99-108. (DOI 10.1016/j.tourman.2015.02.016)

Backer E., Ritchie B. W., 2017, VFR Travel: A Viable Market for Tourism Crisis and Disaster Recovery? International Journal of Tourism Research, 19(4), 400-411. (DOI 10.1002/jtr.2102)

Chen M. H., 2011, The response of hotel performance to international tourism development and crisis events, International Journal of Hospitality Management, 30(1), 200-212. (DOI 10.1016/j.jijhm.2010.06.005)

Dz.U. 2020, poz. 433

Dz.U. 2020, poz. 491

Dz.U. 2020, poz. 695

Dz.U. 2020, poz. 695

Floyd M. F., Gibson H., Pennington-Gray L., Thapa B., 2004 , The effect of risk perceptions on intentions to travel in the aftermath of September 11, 2001, Journal of Travel \& Tourism Marketing, 15(2-3), 19-38. (DOI 10.1300/J073v15n02_02)

Fuchs G., Reichel A., 2011, An exploratory inquiry into destination risk perceptions and risk reduction strategies of first time vs. repeat visitors to a highly volatile destination, Tourism Management, 32(2), 266-276. (DOI 10.1016/j. tourman.2010.01.012)

Hon A. H. Y., Bloom M., Crant M., 2014, Overcoming Resistance to Change and Enhancing Creative Per- formance, Journal of Management, 40(3), 919-941. (DOI 10.1177/0149206311415418)

Hui D. S., I Azhar E., Madani T. A., Ntoumi F., Kock R., Dar O., Ippolito G., Mchugh T. D., Memish Z. A., Drosten C., Zumla A., Petersen E., 2020, The continuing 2019-nCoV epidemic threat of novel coronaviruses to global health - The latest 2019 novel coronavirus outbreak in Wuhan, China, International Journal of Infectious Diseases, 91, 264-266. (DOI 10.1016/j.ijid.2020.01.009)

Kozak M., Crotts J. C., Law R, 2007, The impact of the perception of risk on international travellers, International Journal of Tourism Research, 9(4), 233-242. (DOI 10.1002/jtr.607)

Lauer S. A., Grantz K. H., Bi Q., Jones F. K., Zheng Q., Meredith H. R., Azman A. S., Reich N. G., Lessler J., 2020, The Incubation Period of Coronavirus Disease 2019 (COVID-19) From Publicly Reported Confirmed Cases: Estimation and Application, Annals of Internal Medicine. (DOI 10.7326/M200504)

Law R., 2006, The perceived impact of risks on travel decisions, International Journal of Tourism Research, 8(4), 289-300. (DOI 10.1002/jtr.576)

Lee C.-C., Chen C.-J., 2011, The reaction of elderly Asian tourists to avian influenza and SARS, Tourism Management, 32(6), 1421-1422. (DOI 10.1016/j.tourman.2010.12.009)

Lee C.-K., Song H.-J., Bendle L. J., Kim M.-J., Han H., 2012, The impact of non-pharmaceutical interventions for 2009 H1N1 influenza on travel intentions: A model of goal-directed behavior, Tourism Management, 33(1), 89-99. (DOI 10.1016/j.tourman.2011.02.006)

Mao C.-K., Ding C. G., Lee H.-Y., 2010, Post-SARS tourist arrival recovery patterns: An analysis based on a catastrophe theory, Tourism Management, 31(6), 855-861. (DOI 10.1016/j.tourman.2009.09.003)

Mason P., Grabowski P., Du W., 2005, Severe acute respiratory syndrome, tourism and the media, International Journal of Tourism Research, 7(1), 11-21. (DOI 10.1002/jtr.519)

McKercher B., Chon K., 2004, The Over-Reaction to SARS and the Collapse of Asian Tourism, Annals of Tourism Research, 31(3), 716-719. (DOI 10.1016/j.annals.2003.11.002)

Senbeto D. L., Hon A. H. Y., 2020, The impacts of social and economic crises on tourist behaviour and expenditure: an evolutionary approach, Current Issues in Tourism, 23(6), 740-755. (DOI 10.1080/13683500.2018.1546674)

Song H., Lin S., Witt S. F., Zhang X., 2011, Impact of financial/economic crisis on demand for hotel rooms in Hong Kong, Tourism Management, 32(1), 172-186. (DOI 10.1016/j. tourman.2010.05.006)

Uriely N., Maoz D., Reichel A., 2007, Rationalising Terrorrelated risks: The Case of Israeli Tourists in Sinai, International Journal of Tourism Research, 9(1), 1-8. (DOI 10.1002/ jtr.587)

Yang Y., Zhang H., Chen X., 2020, Coronavirus pandemic and tourism: Dynamic stochastic generalequilibrium modeling of infectious disease outbreak, Annals of Tourism Research. (DOI 10.1016/j.annals.2020.102913) 